\title{
Effect of Integrated Nutrient Management on Economics, Sugar Quality and Uptake of Parching Sorghum Genotypes
}

\author{
Seema M. Nemade ${ }^{1 *}$, N.B. Mohod ${ }^{2}$, V.R. Thakur ${ }^{1}$ and N.K. Shinde ${ }^{2}$ \\ ${ }^{1}$ COA, Dr. P.D.K.V., Akola, India \\ ${ }^{2}$ Department of Agronomy, Dr. P.D.K.V., Akola, India \\ *Corresponding author
}

\begin{tabular}{|l|}
\hline Ke y w o r d s \\
Parching sorghum, \\
INM, Quality, \\
Parching sorghum \\
genotypes, Uptake, \\
Economics \\
\hline Article Info \\
\hline $\begin{array}{l}\text { Accepted: } \\
\text { 04 June } 2019 \\
\text { Available Online: } \\
\text { 10 July } 2019\end{array}$ \\
\hline
\end{tabular}

\section{A B S T R A C T}

A field experiment was carried out on 'Effect of integrated nutrient management on yield and quality of parching sorghum for identifying an ideal combination of Zinc, organic and inorganic nutrient sources for getting better quality, more net return and uptake of nutrients of kharif parching sorghum. The experiment was carried out at the farm of CRS, Sorghum Research Unit, Dr. PDKV, Akola, during Kharif season of 2016-17 on clayey loam soil. A Factorial Randomized Block Design was used for field experiment in which 12 treatment combinations were replicated thrice to evaluate treatment effect having three parching sorghum varieties. viz., $\mathrm{V}_{1}$-PKV Ashwini, V2-Malkapurwani (Local), $\mathrm{V}_{3}$-PDKV Kartiki and four nutrient management treatments viz., $\mathrm{T}_{1}-10 \mathrm{t} \mathrm{FYM} / \mathrm{ha}, \mathrm{T}_{2}-100 \% \mathrm{RDF}$ (80:40:40) $\mathrm{kg} \mathrm{N}, \mathrm{P}_{2} \mathrm{O}_{5}$, and $\mathrm{K}_{2} \mathrm{O} / \mathrm{ha}, \mathrm{T}_{3}-75 \% \mathrm{RDF}+5 \mathrm{t} \mathrm{FYM} \mathrm{/ha+ZnSO} \mathrm{Z}_{4} 25 \mathrm{~kg} / \mathrm{ha}, \mathrm{T}_{4}-100 \% \mathrm{RDF}+$ $\mathrm{ZnSO}_{4} 25 \mathrm{~kg} / \mathrm{ha}$. Among the varieties PDKV Kartiki $\left(\mathrm{V}_{3}\right)$ recorded significantly higher gross monetary returns (Rs /ha), net monetary returns (Rs /ha), and B: C ratio. However, higher non reducing sugar content (\%) and total sugar content (\%) was recorded by PDKV Kartiki $\left(\mathrm{V}_{3}\right)$ and PKV Ashwini $\left(\mathrm{V}_{1}\right)$ recorded significantly lowest reducing sugar content $(\%)$. The total uptake of nutrients was maximum of Malkapur wani. However treatment $\mathrm{T}_{1}$ $10 \mathrm{t}$ FYM /ha is superior in case of reducing sugar content (0.40). Non reducing sugar content and total sugar content in grain was significantly maximum with application of $75 \% \mathrm{RDF}+5 \mathrm{t} \mathrm{FYM} / \mathrm{ha}+\mathrm{ZnSO}_{4} 25 \mathrm{~kg}\left(\mathrm{~T}_{3}\right)$, similarly total NPK uptake of grain and fodder was also significantly maximum with the same treatment. The, gross monetary returns, and net monetary returns were maximum with the same treatment. However benefit to cost ratio was maximum in $100 \% \mathrm{RDF}$ inorganic $+\mathrm{ZnSO}_{4} 25 \mathrm{~kg} / \mathrm{ha}\left(\mathrm{T}_{4}\right)$.

\section{Introduction}

The parching sorghum is eaten at soft dough stage as table purpose and zinc is an essential nutrient for human health. Importance of application of zinc with INM can be is important for maintaining soil health and also for improving productivity of the sorghum at soft dough stage and increasing the content of this nutrient in grain. Since the possibility of horizontal expansion or putting more area under cultivation is difficult, future augmentation in yield should have to be harnessed vertically through increase in 
productivity by judicious management of all input especially nutrients.

Parching sorghum is eaten in milk stage of grain and it gives 2-3 times more rates as compare to the grain sorghum. It can develop a small entrepreneurship for farmers. Application of micronutrient fertilizers through soil application is the most efficient and economical method of getting these nutrients into the crops.

Use of organic manure with optimum rate of fertilizer under intensive farming system increases the turnover of nutrients in soil plant system (Nambiar and Abrol, 1989). Long term experiment have indicated the favorable effect of FYM on physical properties of soil and also as a source of plant nutrients which are released on its mineralization and become available to plant. Similarly, zinc is an essential nutrient for human health. It is vital for many biological functions in the human body. The adult body contains $2-3 \mathrm{~g}$ of zinc. It is present in all parts of the body including organs, tissues, bones, fluids and cells. It is vital for more than 300 enzymes in the human body, activating growth (height, weight and bone development), growth and cell division, immune system, fertility, taste, smell and appetite, skin, hair and nails, and vision.

Micronutrients are important for maintaining soil health and also for increasing productivity of crops. These are needed in very small amounts. The soil must supply micronutrients for desired growth and development of plants. Zinc is one of the 17 essential elements necessary for the normal growth and development of plants. It is among eight micronutrients essential for Zinc extracts a great influence on basic plant life processes, such as (i) nitrogen metabolism, uptake of nitrogen and protein quality; (ii) photosynthesis-chlorophyll synthesis, carbon anhydrase activity; (iii) resistance to abiotic and biotic stresses protection against oxidative damage (Tekale et al., 2009).

So as there is a scope for soil application of zinc for getting this nutrient into the crop and the alternate use of sorghum as parching sorghum can develop an entrepreneurship for farmers.

Therefore, the present study was undertaken with a view to find out the efficient combination of organic, inorganic fertilizers with soil application of zinc for parching sorghum.

\section{Materials and Methods}

A field experiment was carried out to know the suitable combination of organic, inorganic fertilizers and soil application of zinc for increasing the net returns, production, uptake and improving the quality of parching Sorghum at Sorghum Research Unit, Dr. PDKV, Akola, during Kharif season of 201617 on clayey loam soil. An experiment was laid out in the factorial randomized block design with twelve treatment combinations replicated three times.

The soil of the experimental field was clay loam in texture, low in nitrogen, organic carbon, phosphorus and rich in potash content. The soil reaction was found to be slightly alkaline.

There were twelve treatment combinations of three parching sorghum varieties viz. PKV Ashwini $\left(\mathrm{V}_{1}\right)$, Malkapur wani $\left(\mathrm{V}_{2}\right)$ and PDKV Kartiki $\left(\mathrm{V}_{3}\right)$ and four nutrient management treatments viz. $10 \mathrm{t}$ FYM $\left(\mathrm{T}_{1}\right), 100 \% \mathrm{RDF}$ $\left(\mathrm{T}_{2}\right), 75 \% \mathrm{RDF}+5 \mathrm{t} \mathrm{FYM} / \mathrm{ha}+\mathrm{ZnSo}_{4} 25 \mathrm{~kg}$ /ha $\left(\mathrm{T}_{3}\right)$ and $100 \% \mathrm{RDF}+\mathrm{ZnSo}_{4} 25 \mathrm{~kg} / \mathrm{ha}\left(\mathrm{T}_{4}\right)$

The sowing of Sorghum crop has been done in first week of July 2016 and harvested in October 2016 at its dough stage. During the 
crop growing season total rainfall of 595.3 $\mathrm{mm}$ was recorded in 32 rainy days. The overall weather during crop growing season was quite satisfactory. Recommended doses of inorganic fertilizers consisting of $80 \mathrm{~kg} \mathrm{~N}$ and $40 \mathrm{~kg}$ each of $\mathrm{P}_{2} \mathrm{O}_{5}$ and $\mathrm{K}_{2} \mathrm{O} /$ ha were applied to sorghum. For sorghum $\mathrm{N}$ was applied in 2 splits, half at sowing along with entire quantity of $\mathrm{P}_{2} \mathrm{O}_{5}$ and $\mathrm{K}_{2} \mathrm{O}$ and remaining $\mathrm{N}$ was applied 30 days after sowing.

Nitrogen, phosphorus and potassium were applied through urea, single superphosphate and muriate of potash, respectively. Sorghum was sown using seed rate $7.5-10 \mathrm{~kg} / \mathrm{ha}$ with a spacing of $45 \mathrm{~cm} \mathrm{x} 15 \mathrm{~cm}$.

Reducing sugars was determined by Dinitrosalicylic acid Method (Nelson and Somogyi 1952) and total sugars was determined by Anthrone method (Hedge. Je and Hofreiter, 1962) and non-reducing sugar calculated by formula Non reducing sugar = Total sugar - reducing sugar.

\section{Results and Discussion}

Nitrogen, Phosphorous and Potassium Uptake (kg/ha) in Grain and Fodder

\section{Effect of varieties}

The effect of varieties on nitrogen, phosphorous and potassium uptake ( $\mathrm{kg} / \mathrm{ha}$ ) was found to be significant. $\mathrm{V}_{\mathbf{3}}$-PDKV Kartiki recorded significantly higher mean nitrogen, phosphorous and potassium uptake by grain $(28.517 \mathrm{~kg} / \mathrm{ha}, 8.64 \mathrm{~kg} / \mathrm{ha}, 7.95 \mathrm{~kg} / \mathrm{ha}$ respectively) and was superior to other varieties.

In case of fodder Malkapur wani recorded significantly maximum nitrogen uptake and was superior to other varieties. This might be because of the maximum grain and fodder yield given by these respective varieties.

\section{Effect of nutrient management treatment}

The effect of nutrient management treatment on mean nitrogen uptake $(\mathrm{kg} / \mathrm{ha})$ in grain and fodder was found to be significant (Table 3).

Amongst different nutrient management treatment, treatment $\mathrm{T}_{3}-75 \% \mathrm{RDF}+5$ ton FYM /ha $+\mathrm{ZnSo} 425 \mathrm{~kg}$ /ha recorded significantly higher nitrogen, phosphorous and potassium uptake in grain and fodder and it was at par with $\mathrm{T}_{2}$ and $\mathrm{T}_{4}$.

\section{Reducing, non-reducing sugar content (\%) and total sugar content $(\%)$}

\section{Effect of different parching sorghum varieties on}

Effect of varieties on reducing sugar (\%) was significantly different. PKV Ashwini variety is significantly superior and recorded lowest reducing sugar content $(0.31 \%)$.

This might be due to the character of the particular genotype. In case of non-reducing sugar (\%) PDKV Kartiki variety is significantly superior and recorded highest non reducing sugar content $(10.30 \%)$.

The total sugar (\%) was significantly maximum in PDKV Kartiki (10.72\%) and was at par with PKV Ashwini (10.18\%).

\section{Effect of nutrient management}

Significantly lower reducing sugar in the grain was recorded with application of 10 ton FYM $\left(\mathrm{T}_{1}\right)$ which was at par with $\mathrm{T}_{3}$ and $\mathrm{T}_{4}$. Application of $75 \%$ RDF+ $5 \mathrm{t}$ FYM $/ \mathrm{ha}+\mathrm{ZnSo}_{4} 25 \mathrm{~kg} / \mathrm{ha}\left(\mathrm{T}_{3}\right)$ recorded higher non reducing sugar content $(\%)$ and total sugar content $(\%)$ as compared to other treatments. Above results are in conformity with the results obtained by Anonymous (2006) (Table $1)$. 
Table.1 Reducing sugar, non-reducing sugar and total sugar in Sorghum as influenced by different treatments

\begin{tabular}{|c|c|c|c|}
\hline Treatment & $\begin{array}{l}\text { Reducing sugar } \\
(\%)\end{array}$ & $\begin{array}{l}\text { Non reducing sugar } \\
(\%)\end{array}$ & Total sugar $(\%)$ \\
\hline \multicolumn{4}{|l|}{ Factor A- Parching Sorghum Varieties } \\
\hline $\mathrm{V}_{1^{-}}$PKV Ashwini & 0.31 & 9.87 & 10.18 \\
\hline V $_{2}$-Malkapur wani(Local) & 0.52 & 8.62 & 9.14 \\
\hline$V_{3}$-PDKV Kartiki & 0.42 & 10.30 & 10.72 \\
\hline SE (m) \pm & 0.009 & 0.20 & 0.23 \\
\hline CD at $5 \%$ & 0.03 & 0.57 & 0.68 \\
\hline \multicolumn{4}{|l|}{ Factor B- Nutrient Management } \\
\hline 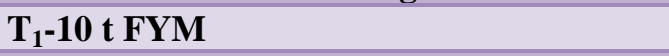 & 0.40 & 8.39 & 8.79 \\
\hline $\mathrm{T}_{2}-100 \%$ RDF & 0.44 & 9.59 & 10.03 \\
\hline $\begin{array}{l}\mathrm{T}_{3}-75 \% \mathrm{RDF}+5 \mathrm{t} \mathrm{FYM} / \mathrm{ha}+\mathrm{ZnSo}_{4} 25 \mathrm{~kg} \\
/ \mathrm{ha}\end{array}$ & 0.41 & 10.51 & 10.92 \\
\hline $\mathrm{T}_{4}-100 \% \mathrm{RDF}+\mathrm{ZnSo}_{4} 25 \mathrm{~kg} / \mathrm{ha}$ & 0.42 & 9.90 & 10.32 \\
\hline $\mathbf{S E}(\mathbf{m}) \pm$ & 0.010 & 0.23 & 0.27 \\
\hline CD at $5 \%$ & 0.03 & 0.66 & 0.78 \\
\hline \multicolumn{4}{|l|}{ Interaction (AXB) } \\
\hline $\mathrm{SE}(\mathrm{m}) \pm$ & 0.017 & 0.39 & 0.46 \\
\hline CD at $5 \%$ & NS & NS & NS \\
\hline G & 0.42 & 9.60 & 10.02 \\
\hline
\end{tabular}

Table.2 Yield and Economics of parching sorghum under various treatments

\begin{tabular}{|c|c|c|c|c|c|c|}
\hline Treatment & $\begin{array}{l}\text { Green } \\
\text { hurda } \\
\text { yield } \\
\text { /ha }\end{array}$ & $\begin{array}{l}\text { Dry } \\
\text { fodder } \\
\text { yield q } \\
\text { /ha }\end{array}$ & $\begin{array}{l}\text { Gross } \\
\text { monetary } \\
\text { returns } \\
\text { (Rs. /ha) }\end{array}$ & $\begin{array}{l}\text { Cost of } \\
\text { cultivation } \\
\text { (Rs. /ha) }\end{array}$ & $\begin{array}{l}\text { Net } \\
\text { monetary } \\
\text { returns } \\
\text { (Rs. /ha) }\end{array}$ & $\begin{array}{l}\text { Cost } \\
\text { benefits } \\
\text { ratio }\end{array}$ \\
\hline \multicolumn{7}{|c|}{ Factor A- Parching Sorghum Varieties } \\
\hline $\mathbf{V}_{1}-$ PKV Ashwini & 33.15 & 123.32 & 113700 & 32612 & 81088 & 2.48 \\
\hline $\mathbf{V}_{2}$-Malkapur wani(Local) & 30.41 & 135.18 & 109818 & 32612 & 77207 & 2.36 \\
\hline$V_{3}$-PDKV Kartiki & 35.98 & 116.18 & 118997 & 32612 & 86395 & 2.64 \\
\hline $\mathrm{SE}(\mathbf{m}) \pm$ & 0.75 & 2.76 & 1876 & & 1876 & \\
\hline CD at $5 \%$ & 2.19 & 8.06 & 5501 & & 5501 & \\
\hline \multicolumn{7}{|l|}{ Factor B- Nutrient Management } \\
\hline$T_{1}-10$ t FYM & 27.35 & 113.73 & 96801 & 45050 & 51751 & 1.14 \\
\hline $\mathrm{T}_{2}-100 \% \mathrm{RDF}$ & 32.47 & 121.24 & 111498 & 24256 & 87241 & 3.60 \\
\hline $\begin{array}{l}\mathrm{T}_{3}-75 \%+5 \mathrm{t} \text { FYM } / \mathrm{ha}+\mathrm{ZnSo}_{4} 25 \\
\mathrm{~kg} / \mathrm{ha}\end{array}$ & 39.97 & 137.71 & 134361 & 35883 & 98478 & 2.74 \\
\hline $\mathrm{T}_{4}-100 \% \mathrm{RDF}+\mathrm{ZnSo}_{4} 25 \mathrm{~kg} / \mathrm{ha}$ & 35.60 & 125.72 & 120417 & 25243 & 95174 & 3.77 \\
\hline $\mathrm{SE}(\mathrm{m}) \pm$ & 0.87 & 3.19 & 2966 & & 2966 & \\
\hline CD at $5 \%$ & 2.53 & 9.31 & 8698 & & 8698 & \\
\hline \multicolumn{7}{|l|}{ Interaction (AXB) } \\
\hline $\mathrm{SE}(\mathbf{m}) \pm$ & 1.50 & 5.52 & & & 3971 & \\
\hline CD at $5 \%$ & NS & NS & NS & & NS & \\
\hline GM & 33.85 & 124.89 & 115085 & 32610 & 82476 & 2.67 \\
\hline
\end{tabular}


Table.3 Nitrogen, phosphorus and potassium uptake $(\mathrm{kg} / \mathrm{ha}$ ) by sorghum as influenced by different treatments

\begin{tabular}{|c|c|c|c|c|c|c|c|c|c|}
\hline \multirow[t]{2}{*}{ Treatment } & \multicolumn{3}{|c|}{$\begin{array}{l}\text { Nitrogen uptake } \\
(\mathrm{kg} / \mathrm{ha})\end{array}$} & \multicolumn{3}{|c|}{$\begin{array}{l}\text { Phosphorus uptake } \\
\text { (kg/ha) }\end{array}$} & \multicolumn{3}{|c|}{$\begin{array}{l}\text { Potassium uptake } \\
\text { (kg /ha) }\end{array}$} \\
\hline & Grain & Fodder & Total & Grain & Fodder & Total & Grain & Fodder & Total \\
\hline \multicolumn{10}{|c|}{ Factor A- Parching Sorghum Varieties } \\
\hline $\mathrm{V}_{1}$ - PKV Ashwini & 25.58 & 69.54 & 95.13 & 6.75 & 28.58 & 35.33 & 6.51 & 35.63 & 42.15 \\
\hline $\begin{array}{l}\text { V } \\
\text { wani(Local) }\end{array}$ & 23.39 & 77.14 & 100.54 & 5.75 & 33.30 & 39.06 & 5.41 & 49.05 & 54.46 \\
\hline V-PDKV Kartiki & 28.51 & 73.41 & 101.93 & 8.64 & 28.70 & 37.34 & 7.95 & 26.70 & 34.65 \\
\hline SE $(\mathbf{m}) \pm$ & 0.62 & 2.09 & 2.11 & 0.21 & 0.74 & 0.77 & 0.18 & 0.71 & 0.75 \\
\hline CD at $5 \%$ & 1.83 & 5.41 & 6.16 & 0.64 & 2.17 & 2.25 & 0.55 & 2.09 & 2.21 \\
\hline \multicolumn{10}{|c|}{ Factor B- Nutrient Management } \\
\hline$T_{1}-10$ t FYM & 20.18 & 63.19 & 83.38 & 5.29 & 25.55 & 30.84 & 4.94 & 31.20 & 36.14 \\
\hline$T_{2}-100 \%$ RDF & 25.21 & 75.82 & 101.03 & 7.20 & 28.45 & 35.65 & 6.49 & 34.15 & 40.64 \\
\hline $\begin{array}{l}\mathrm{T}_{3}-75 \% \mathrm{RDF}+5 \mathrm{t} \mathrm{FYM} \\
/ \mathrm{ha}+\mathrm{ZnSo}_{4} 25 \mathrm{~kg} / \mathrm{ha}\end{array}$ & 30.31 & 79.04 & 109.35 & 8.06 & 35.64 & 43.70 & 7.55 & 43.98 & 51.53 \\
\hline $\begin{array}{l}\mathrm{T}_{4}-100 \% \\
25 \mathrm{~kg} / \mathrm{ha}\end{array}$ & 27.61 & 75.41 & 103.03 & 7.64 & 31.14 & 38.79 & 7.52 & 39.17 & 46.69 \\
\hline SE (m) \pm & 0.72 & 2.42 & 2.43 & 0.25 & 0.86 & 0.89 & 0.21 & 0.82 & 0.87 \\
\hline CD at $5 \%$ & 2.12 & 7.06 & 7.11 & 0.74 & 2.51 & 2.60 & 0.63 & 2.41 & 2.55 \\
\hline \multicolumn{10}{|l|}{ Interaction (AXB) } \\
\hline SE $(\mathbf{m}) \pm$ & 1.25 & 4.19 & 4.22 & 0.43 & 1.49 & 1.54 & 0.37 & 1.43 & 1.51 \\
\hline CD at $5 \%$ & NS & NS & NS & NS & NS & NS & NS & NS & NS \\
\hline GM & 25.83 & 73.36 & 99.20 & 7.05 & 30.19 & 37.24 & 6.62 & 37.13 & 43.75 \\
\hline
\end{tabular}

GMR, NMR (Rs /ha) and B: C ratio

Effect of varieties

The effect of varieties on GMR, NMR (Rs /ha) and B: C ratio was found to be significant. Variety $\mathrm{V}_{\mathbf{3}}$-PDKV Kartiki recorded significantly higher mean GMR (Rs. 153035/ha), NMR (Rs. 74779/ha) and B: C ratio. This might be due to the higher hurda yield obtained with this variety (Table 2).

\section{Effect of nutrient management treatment}

Amongst different nutrient management treatment, treatment $\mathrm{T}_{3}-75 \% \mathrm{RDF}+5$ ton FYM /ha +ZnSo4 $25 \mathrm{~kg}$ /ha recorded significantly higher GMR (Rs. 37010/ha) NMR (Rs. 74779/ha) and B: C ratio and was significantly superior over other treatments.

Syed Ismail et al., (2009) reported that integrated use of inorganic fertilizers, 
organics, biofertilizers and micronutrients based on soil test values were better to increase grain yield, green stalk yield, juice extraction percentage, brix and non-reducing sugars, concentration of nutrients in stover and grain as well as their uptake by sweet sorghum crop was also more in integrated nutrient supply system as compared to inorganic fertilizer alone.

The results are also agreed with the results of Venugopal et al., (2015) who recorded that INM practice by applying FYM or crop residues along with optimum NPK fertilizers increased the sorghum grain yield and nutrient uptake significantly over application of only RDF.

Similarly Raghuwanshi and Umat (1994) also observed that under integrated nutrient management in sorghum the treatments FYM, crop residue and green manure in combination with inorganic fertilizers proved to be better in enhancing the total nutrient uptake by the crop on medium black soil. The results are also in conformity with the results obtained by Patil et al., (1995). Similar result were indicated by Gaikwad et al., (2018) that the application inorganic and organic combination of treatment T7-75\% RDN+25\% $\mathrm{N}$ through Vermicompost +ZnSO4@20kg/ ha produced higher yield as well as, high $\mathrm{B}$ : C ratio, gross monetary returns, and net monetary.

Thus it can be concluded from the experimental results that the parching sorghum variety PDKV Kartiki is the best parching sorghum variety for obtaining higher nutrient uptake, net returns and lower reducing sugar content and higher non reducing and total sugar content. Whereas, application of $75 \% \mathrm{RDF}+5 \mathrm{t}$ FYM $/ \mathrm{ha}+\mathrm{ZnSo} 425 \mathrm{~kg} / \mathrm{ha}$ is the best proposition for obtaining higher nutrient uptake, net returns and lower reducing sugar content and higher non reducing and total sugar content.

\section{References}

Gaikwad M. D., Karanjikar P. N., Gaikwad J. D. and P. K. Waghmare. (2018). Effect of Integrated Nutrient Management on Yield, Yield Attributes and Economy of Kharif Sorghum (Sorghum bicolour L.) in Marathawada Region. Int.J.Curr.Microbiol.App.Sci (2018) Special Issue-6: 2953-2957

Hedge, J.E. and Hofreiter, B.T. 1962. Carbohydrate chemistry 17. Whistler, R.L. and Be Miller, J. N., Eds., Academic Press, New York.

Nambiar, K.K.M. and I.P. Aroal (1989): Long term fertilizer experiment in India. Fertilizer News. 34 (4): 11-20.

Patil, R.K., Naphadc, K.T. and Varade, P.A. (1995): Effect of organics and inorganics on yield and nutrient uptake by sorghum and wheat. State level seminar on integrated nutrient management for sustainable agriculture, Rahuri chapter. Indian Soc. Soil Sci. M.P.K.V., Rahuri (M.S.). Abst. 28.

Raghuwanshi, R.K.S. and Umat, R. (1994): Integrated nutrient management in sorghum (Sorghum bicolor) - wheat (Triticum aestivum) cropping system. Indian J. Agron. 39 (2): 193-197.

Somogyi, M. 1952. J boil Chem. 200, 245.

Syed Ismail, B.K. Arbad and J.J. Syed.2009. Impact of integrated nutrient management practices on yield, juice quality and nutrient uptake in sweet sorghum [Sorghum biocolor (L.) Moench] grown on vertisol. Asian Journal of Bio Science, 4 (1): 100-102

Tekale, R. P., Guhey, A., and Agrawal, K. (2009). Impact of boron, zink and IAA on growth, dry matter accumulation and sink potential of pigeon pea (Cajanus Cajan L.). Agric. Sci. Digest., 29(4), 246-249. 
Venugopal G., Sharma, SHK, Abdul Aziz Qureshi and Chandrashekhara Rao Palli. 2015. Sorghum yield and nutrient uptake under long term nutrient management practices in Sorghum-
Sunflower cropping system. International Journal of Agriculture, Environment and Biotechnology. 8(4): 899-906.

\section{How to cite this article:}

Seema M. Nemade, N.B. Mohod, V.R. Thakur and Shinde, N.K. 2019. Effect of Integrated Nutrient Management on Economics, Sugar Quality and Uptake of Parching Sorghum Genotypes. Int.J.Curr.Microbiol.App.Sci. 8(07): 359-365.

doi: https://doi.org/10.20546/ijcmas.2019.807.044 